\title{
Analisis Kontribusi Pajak Reklame terhadap Pendapatan Asli Daerah di Kota Samarinda
}

\author{
Devy Putri Milanda \\ Universitas Widya Gama Mahakam Samarinda \\ Program Studi Akuntansi \\ devyudin@yahoo.com \\ Gregorius, Dian Mariana, Jekyus \\ Universitas Widya Gama Mahakam Samarinda
}

\begin{abstract}
ABSTRAK
Pendapatan Asli Daerah adalah realisasi jumlah penerimaan pajak dan non pajak di Kota Samarinda dari tahun 2012 sampai 2016. Pajak Reklame ialah realisasi nilai (uang) yang dipungut dari wajib pajak atas penyelenggaraan reklame yang ada di Kota Samarinda dari tahun 2012 sampai 2016 sebagai salah satu sumber bagi pembiayaan pemerintahan dan peningkatan Pendapatan Asli Daerah dan Kontribusi Pajak Reklame adalah sumbangan Pajak Reklame dalam meningkatkan Pendapatan Asli Daerah Kota Samarinda dari tahun 2012 sampai 2016.

Penelitian ini merupakan penelitian deskriptif kuantitatif, dimana objek yang dievaluasi adalah Kontribusi Pajak Reklame. Penelitian ini merupakan penelitian analisis komparatif deskriptif yaitu penelitian ini dengan cara membandingkan Kontribusi pajak Reklame dari tahun ketahun yaitu periode 2012-2016.

Dari hasil analisis diketahui Kontribusi Pajak Reklame terhadap Pendapatan Asli Daerah Kota Samarinda periode 2012-2016 dikategorikan sangat kurang berkontribusi. Kurangnya Kontribusi Pajak Reklame yang kecil terhadap PAD juga disebabkan oleh kebijakan Pemerintah Kota Samarinda yang relative kecil dalam menetapkan target untuk penerimaan Pajak Reklame Di Kota Samarinda. Serta meningkatnya pemesanan reklame di Kota Samarinda tidak diikuti dengan pengawasan dan control kepada wajib pajak sehingga masih banyak kebocoran yang terjadi dan menyebabkan banyak terdapat reklamereklame liar dan para wajib pajak yang masih menunggak dan tidak teridentifikasi dengan tepat.
\end{abstract}

\section{Kata kunci : Pendapatan Asli Daerah, Pajak Reklame, Kontribusi Pajak Reklame}




\subsection{Latar Belakang}

Pemerintah daerah dalam melaksanakan tugas pemerintahan dan pembangunan senantiasa memerlukan sumber penerimaan yang dapat diandalkan. Sumber penerimaan ini digunakan untuk membiayai segala kebutuhan daerah dalam menjalankan roda pemerintahan. Dalam sejarah pemerintahan daerah di Indonesia, sejak Indonesia merdeka sampai saat ini pajak dan retribusi daerah telah menjadi sumber penerimaan yang paling besar bagi daerah. Kebutuhan ini semakin dirasakan oleh daerah terutama sejak diberlakukannya otonomi daerah di Indonesia. Otonomi daerah memungkinkan pemerintah daerah untuk menggali sedalam - dalamnya sekaligus seluas - luasnya potensi daerah yang dimilikinya yang bisa dijual untuk memenuhi kebutuhannya khususnya untuk membiayai pembangunan daerahnya agar tidak hanya tergantung subsidi dari pemerintah pusat, yang selama ini masih menjadi sumber utama penerimaan daerah.

Undang-Undang Nomor 32 Tahun 2004 tentang Pemerintahan Daerah dan Undang-Undang Nomor 33 Tahun 2004 tentang Perimbangan Keuangan antara Pemerintah Pusat dan Daerah menetapkan bahwa pendapatan daerah bersumber dari tiga kelompok, yaitu :

1. Pendapatan Asli Daerah (PAD), yaitu pendapatan yang diperoleh daerah dan dipungut berdasarkan peraturan daerah sesuai dengan peraturan perundang undangan meliputi
a. Pajak daerah.
b. Retribusi daerah, termasuk hasil dari pelayanan Badan Layanan Umum (BLU) daerah
c. Hasil pengelolaan kekayaan yang dipisahkan, antara lain bagian laba dari BUMD, hasil kerja sama dengan pihak ketiga
d. Lain-lain PAD yang sah

2. Dana perimbangan, yaitu dana yang bersumber dari pendapatan APBN yang dialokasikan kepada daerah untuk mendanai kebutuhan daerah dalam rangka pelaksanaan desentralisasi.

3. Lain-lain pendapatan daerah yang sah

Salah satu sumber Pendapatan Asli Daerah yang mempunyai prospek cukup baik adalah pajak daerah. Menurut Undang-Undang No. 34 Tahun 2000 Tentang Pajak dan Retribusi Daerah yang termasuk pajak daerah adalah :
a) Pajak hotel
b) Pajak restoran
c) Pajak hiburan
d) Pajak reklame
e) Pajak penerangan jalan
f) Pajak parkir
g) Pajak pengambilan bahan galian golongan $\mathrm{C}$
h) Bila dilihat dari kontribusinya bagi Pajak Daerah, Pajak Reklame sebagai
salah satu sumber Pendapatan Daerah yang berpotensi dan dapat dilakukan 
pemungutan secara efisien, efektif, dan ekonomis sehingga dapat lebih berperan dalam usaha peningkatan Pendapatan Asli Daerah di Kota Samarinda. Sehingga diharapkan dari pajak reklame tersebut menjadikan penerimaan pajak daerah meningkat secara signifikan dari tahun ke tahun. Diharapkan dengan berlakunya Peraturan Daerah ini adanya peningkatan pemasukan pajak daerah untuk Kota Samarinda khususnya untuk pajak reklame. Jika diamati dan dilihat perkembangan pembangunan yang terjadi di Kota Samarinda beberapa tahun kebelakang mengalami peningkatan yang cukup signifikan. Hal ini mengindikasikan bahwa pemerintah daerah khususnya Pemerintah Daerah Kota Samarinda dapat dikatakan berhasil didalam mengelola daerahnya. Hal ini ditandai dengan adanya berbagai fasilitas umum yang semakin kondusif keberadaannya, kemudian juga sarana dan prasarana yang mendukung mobilitas penduduk yang juga semakin terjaga. Disamping itu juga mulai berkembangnya iklim usaha dengan ditandai dengan bermunculannya usaha-usaha baru baik berupa cabang perusahaan ataupun perusahaan baru yang ada di Kota Samarinda, yang ditandai dengan bermunculannya reklame-reklame atau iklan produk-produk baru.

Tabel 1.1. Ringkasan Pendapatan Daearah, Pendapatan Asli Daerah, dan Pajak Reklame.

\begin{tabular}{|l|l|l|l|}
\hline Tahun & $\begin{array}{l}\text { Realisasi Pendapatan } \\
\text { Daerah }\end{array}$ & $\begin{array}{l}\text { Pendapatan } \\
\text { Daerah }\end{array}$ & Pajak Reklame \\
\hline 2012 & Rp 2.703.368.601.770 & Rp 263.902.471.375 & Rp 5.416.978.996 \\
\hline 2013 & Rp 2.567.673.073.696 & Rp 338.198.739.081 & Rp 6.495.666.709 \\
\hline 2014 & Rp 2.845.030.033.447 & Rp 435.492.590.746 & Rp 6.927.767.722 \\
\hline 2015 & Rp 2.847.805.750.674 & Rp 408.195.248.641 & Rp 7.511.962.861 \\
\hline 2016 & Rp 2.734.700.767.930 & Rp 391.478.411.832 & Rp 7.643.499.832 \\
\hline
\end{tabular}

Sumber : Badan Pendapatan Daerah Kota Samarinda

Berdasarkan Tabel diatas, pajak reklame merupakan objek yang penting karena penerimaan Pajak Daerah terutama Pajak Reklame dapat memberikan kontribusi atau sumbangsih dan andil yang tidak sedikit dalam meningkatkan Pendapatan Asli Daerah guna mensukseskan Pembangunan Daerah Kota Samarinda pada khususnya dan Pembangunan Nasional pada umumnya. 


\section{Kerangka Teoritis}

\section{Pendapatan Asli Daerah}

Pengertian Pendapatan Asli Daerah Menurut Undang-Undang No. 28 Tahun 2009 yaitu sumber keuangan daerah yang digali dari wilayah daerah yang bersangkutan yang terdiri dari hasil pajak daerah, hasil retribusi daerah, hasil pengelolaan kekayaan daerah yang dipisahkan dan lain lain pendapatan asli daerah yang sah.

Hal ini sesuai dengan klasifikasi Pendapatan Asli Daerah yang terbaru berdasarkan Permendagri No. 13 tahun 2006 yang terdiri dari : Pajak Daerah, Retribusi Daerah, Hasil pengelolaan daerah yang dipisahkan, dan lain-lain pendapatan daerah yang sah. Jenis pajak Daerah dan retribusi daearah dirinci menurut objek pendapatan sesuai dengan undang-undang pajak daerah dan retribusi daerah. Jenis hasil pengelolaan kekayaan daerah yang dipisahkan dirinci menurut objek pendapatan yang mencakup bagian laba atas penyertaan modal pada perusahaan milik daerah/BUMD, bagian laba atas penyertaan modal pada perusahaan milik swasta atau kelompok usaha masyarakat. Jenis lain-lain PAD yang sah disediakan untuk menganggarkan penerimaan daerah yang tidak termasuk dalam pajak daerah, retribusi daerah dan hasil pengelolaan kekayaan daerah yang dipisahkan dirinci menurut objek pendapatan yang mencakup hasilhasil penjualan kekayaan daerah yang tidak dipisahkan, jasa giro, pendapatan bunga, penerimaan atas tuntutan ganti rugi daerah, penerimaan komisi, potongan,

\section{Pajak Daerah}

Pajak daerah menurut Erly Suandy ialah iuran yang wajib dilakukan oleh pribadi atau badan kepada daerah tanpa imbalan langsung yang seimbang yang dapat dilaksanakan berdasarkan peraturan perundang-undangan yang berlaku, yang digunakan untuk membiayai penyelenggaraan pemerintah daerah dan pembangunan daerah.

Dewasa ini, pajak daerah terdiri dari berbagai jenis pajak yang terkait dengan berbagai sendi kehidupan masyarakat. Masing-masing jenis pajak daerah memiliki objek, subjek, tarifdan berbagai ketentuan pengenaan tersendiri, yang mungkin berbeda dengan jenis pajak daerah lainnya.

\section{Retribusi Daerah}

Menurut Marihot "Retribusi adalah pembayaran wajib dari penduduk kepada negara karena adanya jasa tertentu yang diberikan oleh negara dari penduduknya secara perseorangan".

Jasa tersebut dapat dikatakan bersifat langsung, yaitu hanya yang membayar retribusi yang menikmati balas jasa dari negara. Salah satu contoh retribusi adalah retribusi pelayanan kesehatan pada Rumah Sakit yang dikelolah oleh pemerintah.setiap orang yang ingin mendapatkan pelayannan kesehatan dirumah sakit pemerintah harus retribusi yang ditetapkan oleh pemerintah sebagai pembayaran atas jasa pelayanan kesehatan dirumah sakit pemerintah. Akan tetapi, 
tidak ada paksaan secara yuridis kepada pasien (anggota masyarakat) untuk membayar retribusi karena setiap orang bebas untuk memilih pelayanan kesehatan yang diinginkannya.

\section{Hasil Pengelolaan Kekayaan Daerah lainnya yang dipisahkan}

Menurut Halim "hasil pengelolaan kekayaan milik daerah yang dipisahkan merupakan penerimaan daerah yang berasal dari pengelolaan kekayaan daerah yang dipisahkan". Jenis pendapatan ini dirinci menurut objek pendapatan yang mencakup :

1. Bagian laba atas penyertaan modal pada perusahaan milik daerah/BUMD

2. Bagian laba atas penyertaan modal pada perusahaan milik negara/ BUMN

3. Bagian laba atas penyertaan modal pada perusahaan milik Swasta atau kelompok usaha masyarakat.

Kekayaan daerah yang dipisahkan berarti kekayaan daerah yang dilepaskan dan penguasaan umum yang dipertanggungjawabkan melalui anggaran belanja daerah dan dimaksudkan untuk dikuasai dan dipertanggungjawabkan sendiri.

\section{Lain-lain Pendapatan Asli Daerah yang Sah}

Menurut Abdul Halim, "lain-lain pendapatan asli daearah yang sah merupakan penerimaan daerah yang berasal dari lain-lain milik pemerintah daerah". berikut:

Jenis pendapatan Asli Daerah Yang Sah ini meliputi objek pendapatan

2. Hasil penjualan asset daerahyang tidak dipisahkan

1. Jasa giro

2. Pendapatan bunga

3. Penerimaan atas tuntutan ganti kerugian daerah

4. Penerimaan komisi, potongan ataupun bentuk lain sebagai akibat dari penjualan, pengadaan barang dan jasa oleh daerah

5. Penerimaan keuangan dari selisih nilai tukar rupiah

6. Pendapatan denda atas keterlambatan pelaksanaan pekerjaan

7. Pendpatan denda pajak

8. Pendapatan denda retribusi

9. Pendpatan hasil eksekusi atas jaminan

10. Pendapatan dari pengembalian

11. Fasilitas social dan umum

12. Pendapatan dari penyelenggaraanpendidikan dan pelatihan

13. Pendapatan dari angsuran/cicilan penjualan.

\section{Dana Perimbangan}

Menurut Sugianto pada bukunya yang berjudul Pajak dan Retribusi Daerah (Pengelolaan Pemerintah Daerah Dalam Aspek Keuangan, Pajak, dan Reribusi 
Daerah) "Dana Perimbangan adalah dana yang bersumber dari pendapatan APBN dialokasikan kepada daerah untuk mendanai kebutuhan daerah dalam rangka pelaksanaan desentralisasi yang meliputi dana bagi hasil, dana alokasi umum, dan dana alokasi khusus".

Dalam UU No. 33 Tahun 2004 tentang Perimbangan Keuangan antara Pemerintah Pusat dengan Pemerintah Daerah Pasal 1 angka 19 disebutkan Dana Perimbangan adalah dana yang bersumber dari epndapatan APBN yang dialokasikan kepada Daerah untuk mendanai Kebutuhan Derah dalam rangka pelaksanaan Desentralisasi. Perimbangan Keuangan antara Pemerintah dan pemerintah Dearah adalah suatu sistem pembagian keuangan yang adil, transparan, dan efisien dalam rangka pendanaan penyelenggaraan Desentralisasi, dengan mempertimbangkan Potensi, Kondisi, dan kebutuhan daerahserta besaran pendanaan penyelenggaraan Dekonsentrasi dan Tugas Pembantuan.

\section{Dasar Hukum Pemungutan Pajak Reklame}

Pemungutan pajak reklame di Indonesia saat ini disasarkan pada dasar hukum yang jelas dan kuat sehingga harus dipatuhi oleh masyarakat dan pihak yang terkait. Dasar hukum pemungutan pajak reklame pada suatu Kabupaten/Kota adalah sebagai berikut :

a. Undang-Undang Nomor 34 Tahun 2000 yang merupakan perubahan atas Undang-Undang Nomor 18 Tahun 1997 tentang Pajak Daerah dan Retribusi Daerah.

b. Peraturan Pemerintah Nomor 65 Tahun 2001 tentang Pajak Daerah.

c.Peraturan Daerah Kabupaten/ Kota yang mengatur tentang Pajak Reklame.

e. Keputusan Bupati/ Walikota yang mengatur tentang Pajak Reklame pada Kabupaten/Kota dimaksud.

\section{Perhitungan Pajak Reklame}

Besarnya pokok pajak reklame yang terutang dihitung dengan cara mengkalikan tarif pajak dengan dasar pengenaan pajak. Secara umum perhitungan pajak reklame adalah sesuai dengan rumus berikut. Rumus 2.1 (Pajak Reklame Terutang)

\begin{tabular}{|l|}
\hline Pajak reklame Terutang = Tarif Pajak x Nilai Sewa Reklame \\
Besarnya pajak terutang dihitung dengan cara mengkalikan Tarıf pajak
\end{tabular} reklame dengan dasar pengenaan pajak, dimana dasar pengenaan pajak adalah nilai sewa reklame.Berikut adalah Contoh Perhitungan Pajak Reklame Produk dan non produk di Kota Samarinda : 
Tabel 2.2 Perhitungan Nilai Sewa Reklame (NSR) Non Produk:

\begin{tabular}{|l|l|c|l|l|l|}
\hline No & Lokasi & $\begin{array}{l}\text { Ukuran/M } \\
\text { Persegi }\end{array}$ & $\begin{array}{l}\text { Jangka } \\
\text { waktu/hari }\end{array}$ & $\begin{array}{l}\text { Ketinggian } \\
\text { Reklame }\end{array}$ & NSR \\
\hline 1 & Protokol A & 1 & 1 & s.d 15 meter & 25.000 \\
\hline 2 & Protokol B & 1 & 1 & s.d 15 meter & 20.000 \\
\hline 3 & Protokol C & 1 & 1 & s.d 15 meter & 15.000 \\
\hline 4 & Ekonomi kelas I & 1 & 1 & s.d 15 meter & 10.000 \\
\hline 5 & Ekonomi kelas II & 1 & 1 & s.d 15 meter & 5.000 \\
\hline 6 & Ekonomi kelas III & 1 & 1 & s.d 15 meter & 3.000 \\
\hline 7 & Lingkungan & 1 & 1 & s.d 15 meter & 2.000 \\
\hline
\end{tabular}

Tabel 2.3 Perhitungan Nilai Sewa Reklame (NSR) Produk:

\begin{tabular}{|l|l|c|l|l|l|}
\hline No & Lokasi & $\begin{array}{l}\text { Ukuran/M } \\
\text { Persegi }\end{array}$ & $\begin{array}{l}\text { Jangka } \\
\text { waktu/hari }\end{array}$ & $\begin{array}{l}\text { Ketinggian } \\
\text { Reklame }\end{array}$ & NSR \\
\hline 1 & Protokol A & 1 & 1 & s.d 15 meter & 125.000 \\
\hline 2 & Protokol B & 1 & 1 & s.d 15 meter & 100.000 \\
\hline 3 & Protokol C & 1 & 1 & s.d 15 meter & 75.000 \\
\hline 4 & Ekonomi kelas I & 1 & 1 & s.d 15 meter & 50.000 \\
\hline 5 & Ekonomi kelas II & 1 & 1 & s.d 15 meter & 25.000 \\
\hline 6 & Ekonomi kelas III & 1 & 1 & s.d 15 meter & 15.000 \\
\hline 7 & Lingkungan & 1 & 1 & s.d 15 meter & 10.000 \\
\hline
\end{tabular}

Berikut ilustrasi untuk memudahkan pemahaman tabel diatas.

Pak Agus ingin memasang baliho dengan besar 3x6 Meter di area Sempaja (termasuk jalan Protokol Kelas A) sebanyak 2 buah selama 7 hari.

Maka perhitungannya sebagai berikut :

18 Meter x 2 buah x Rp. 125.000 x 7 hari x 25\% (Pajak Reklame) = Rp. 7.875 .000

Catatan:

- Biaya tersebut belum termasuk biaya koordinasi dan Dinas Pertamanan

- Untuk reklame rokok dan minuman beralkohol dikenakan tambahan $25 \%$ dari pokok pajak.

\section{Metode Analisis}

Untuk melakukan analisis dan melakukan pembahasan, penulis menggunakan metode analisis deskriptif komparatif. Dalam menganalisis dan menguji kebenaran dari hipotesis yang telah diambil maka digunakan peralatan statistic yang dapat dihitung dengan rumus kontribusi yang digunakan untuk 
mengetahui seberapa besar Kontribusi Pajak Reklame terhadap Pendapatan Asli Daerah di Kota Samarinda. Adapun rumusnya sebagai berikut:

\section{Rumus Kontribusi}

Adapun rumus kontribusi dapat dijabarkan sebagai berikut:

$$
P=\frac{F}{N} \times 100
$$

Dimana:

$\mathrm{P} \quad=$ kontribusi besarnya penerimaan terhadap PAD Kota Samarinda

$\mathrm{F} \quad=$ Total Pajak Reklame setiap tahun

$\mathrm{N} \quad=$ Total Penerimaan Pendapatan Asli Daerah setiap tahun

Tabel 3.1. Alat analisis Deskriptif komparatif

\begin{tabular}{|c|c|c|c|c|}
\hline Tahun & PAD & Pajak Reklame & $\begin{array}{c}\text { Kontribusi } \\
\text { Reklame }\end{array}$ & Kategori \\
\hline 2012 & Rpxxx & Rpxxx & Rpxxx & \\
\hline 2013 & Rpxxx & Rpxxx & Rpxxx & \\
\hline 2014 & Rpxxx & Rpxxx & Rpxxx & \\
\hline 2015 & Rpxxx & Rpxxx & Rpxxx & \\
\hline 2016 & Rpxxx & Rpxxx & Rpxxx & \\
\hline
\end{tabular}

Tabel 3.2

Ukuran kemampuan Keuangan Daerah dilihat dari rasio Kontribusi Pajak Reklame terhadap Pendapatan Asli Daerah berdasarkan standar pusat.

\begin{tabular}{|l|l|l|}
\hline No & $\begin{array}{l}\text { Rasio Pajak Reklame Terhadap } \\
\text { PAD }\end{array}$ & Kategori \\
\hline 1 & $00,00 \%-10,00 \%$ & Sangat Kurang \\
\hline 2 & $10,10 \%-20,00 \%$ & Kurang \\
\hline 3 & $20,10 \%-30,00 \%$ & Sedang \\
\hline 4 & $30,10 \%-40,00 \%$ & Cukup \\
\hline 5 & $40,10 \%-50,00 \%$ & Baik \\
\hline 6 & Diatas $50 \%$ & Sangat Baik \\
\hline
\end{tabular}

Sumber : Penelitian dan Pengembangan Departemen Dalam Negeri Tahun 2012

\section{Analisis Data Hasil Penelitian}

\section{Analisis Kontribusi Pajak Reklame Terhadap PAD Kota Samarinda}

Kontribusi pajak Reklame terhadap Pendapatan Asli Daerah di Kota Samarinda dihitung dengan membandingkan jumlah realisasi pajak Reklame dengan jumlah realisasi pendapatan asli daerah. Besarnya kontribusi pajak Reklame terhadap pendapatan asli daerah di Kota Samarinda dapat dilihat pada tabel 4.1 berikut ini : 
Tabel 4.1

Kontribusi Pajak Reklame Terhadap Pendapatan Asli Daerah Kota Samarinda Tahun 2012-2016

\begin{tabular}{|c|c|c|}
\hline Tahun & $\begin{array}{c}\text { Realisasi Pajak Reklame } \\
(\mathbf{R p})\end{array}$ & $\begin{array}{c}\text { Realisasi PAD } \\
(\mathbf{R p})\end{array}$ \\
\hline 2012 & $5.416 .978 .996,09$ & $263.902 .471 .374,90$ \\
\hline 2013 & $6.495 .666 .709,46$ & $338.198 .739 .081,07$ \\
\hline 2014 & $6.927 .767 .722,43$ & $435.492 .590 .745,66$ \\
\hline 2015 & $7.511 .962 .861,01$ & $408.195 .248 .641,01$ \\
\hline 2016 & $7.043 .499 .832,17$ & $391.478 .411 .832,07$ \\
\hline
\end{tabular}

Sumber : Badan Pendapatan Daerah Kota Samarinda

Kontribusi Pajak Reklame terhadap Pendapatan Asli Daerah di Kota Samarinda dihitung dengan rumus Kontribusi sebagai berikut :

$$
P=\frac{F}{N} \times 100
$$

Dimana:

$\mathrm{P} \quad=$ Kontribusi Besarnya Penerimaan Terhadap PAD Kota Samarinda

$\mathrm{F} \quad=$ Total Pajak Reklame setiap tahun

$\mathrm{N} \quad=$ Total Penerimaan Pendapatan Asli Daerah setiap tahun

Maka hasil Kontribusinya yang dinyatakan dalam persentase (\%) selama 5 tahun terakhir dari tahun 2012 - 2016 dapat dihitung, sebagai berikut :

$5.416 .978 .996,09$

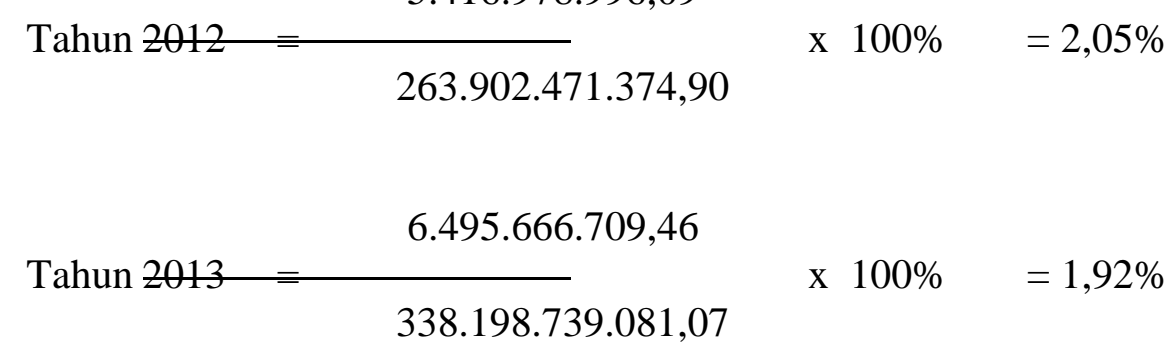

6.927.767.722,43 
Tahun 2014

$435.492 .590 .745,66$

7.511.962.861,01

Tahun $2015=\quad 408.195 .248 .641,01$

7.043.499.832,17

Tahun 2016

$391.478 .411 .832,07$ $\mathrm{x} 100 \%=1,59 \%$

$\mathrm{x} 100 \%=1.84 \%$

$\mathrm{x} 100 \%=1,79 \%$

Tabel 4.2

Kontribusi Pajak Reklame Terhadap Pendapatan Asli Daerah Kota Samarinda Tahun 2012-2016

\begin{tabular}{|c|c|c|c|}
\hline Tahun & $\begin{array}{c}\text { Realisasi Pajak } \\
\text { Reklame (Rp) }\end{array}$ & $\begin{array}{c}\text { Realisasi PAD } \\
\text { (Rp) }\end{array}$ & $\begin{array}{c}\text { Kontribusi } \\
(\%)\end{array}$ \\
\hline 2012 & $5.416 .978 .996,09$ & $263.902 .471 .374,90$ & 2,05 \\
\hline 2013 & $6.495 .666 .709,46$ & $338.198 .739 .081,07$ & 1.92 \\
\hline 2014 & $6.927 .767 .722,43$ & $435.492 .590 .745,66$ & 1.59 \\
\hline 2015 & $7.511 .962 .861,01$ & $408.195 .248 .641,01$ & 1.84 \\
\hline 2016 & $7.043 .499 .832,17$ & $391.478 .411 .832,07$ & 1.79 \\
\hline & Rata-rata & 1.83 \\
\hline
\end{tabular}

Sumber : Badan Pendapatan Daerah Kota Samarinda

Lihat pada tabel 5.1 (Data Diolah)

Dari perhitungan tabel 4.2 diatas menunjukkan persentase kontribusi pajak Reklame mengalami fluktuasi terhadap Pendapatan Asli Daerah Kota Samarinda dari tahun 2012-2016. Dimana, pada tahun 2012 dengan persentase sebesar 2,05\% dari total realisasi pendapatan asli daerah. Pada tahun 2013 kontribusi pajak Reklame mengalami penurunan sebesar $0,13 \%$, yaitu dari $2,05 \%$ menjadi $1,92 \%$. Selanjutnya, pada tahun 2014 kontribusi pajak Reklame mengalami penurunan, yaitu sebesar $1,59 \%$, serta pada tahun 2015 mengalami peningkatan $0.25 \%$, yakni sebesar $1.84 \%$ dan pada tahun 2016 mengalami penurunan sebesar $1.79 \%$. Persentase rata-rata kontribusi total pajak Reklame terhadap Pendapatan Asli Daerah di Kota Samarinda tahun 2012-2016 adalah sebesar 1.83\%. Ini menunjukkan bahwa kontribusi pajak Reklame terhadap Pendapatan Asli Daerah di Kota Samarinda masih tergolong kecil karena berkisaran 0\%-19\%. 
Tabel 4.3

Hasil Analisis Kontribusi Pajak Reklame Terhadap Pendapatan Asli Daerah Kota Samarinda Tahun 2012-2016

\begin{tabular}{|c|c|c|c|c|}
\hline Tahun & PAD & Pajak Reklame & $\begin{array}{c}\text { Kontribusi } \\
\text { Reklame }\end{array}$ & Kategori \\
\hline 2012 & $\begin{array}{c}5.416 .978 .996,0 \\
9\end{array}$ & $\begin{array}{c}263.902 .471 .374,9 \\
0\end{array}$ & 2,05 & $\begin{array}{c}\text { Sangat } \\
\text { Kurang }\end{array}$ \\
\hline 2013 & $\begin{array}{c}6.495 .666 .709,4 \\
6\end{array}$ & $\begin{array}{c}338.198 .739 .081,0 \\
7\end{array}$ & 1,92 & $\begin{array}{c}\text { Sangat } \\
\text { Kurang }\end{array}$ \\
\hline 2014 & $\begin{array}{c}6.927 .767 .722,4 \\
3\end{array}$ & $\begin{array}{c}435.492 .590 .745,6 \\
6\end{array}$ & 1,59 & $\begin{array}{c}\text { Sangat } \\
\text { Kurang }\end{array}$ \\
\hline 2015 & $\begin{array}{c}7.511 .962 .861,0 \\
1\end{array}$ & $\begin{array}{c}408.195 .248 .641,0 \\
1\end{array}$ & 1,84 & $\begin{array}{c}\text { Sangat } \\
\text { Kurang }\end{array}$ \\
\hline 2016 & $\begin{array}{c}7.043 .499 .832,1 \\
7\end{array}$ & $\begin{array}{c}391.478 .411 .832,07 \\
1,79\end{array}$ & $\begin{array}{c}\text { Sangat } \\
\text { Kurang }\end{array}$ \\
\hline
\end{tabular}

Trend Kontribusi Pajak Reklame

\section{Trend Kontribusi Pajak Reklame periode 2012-2016}

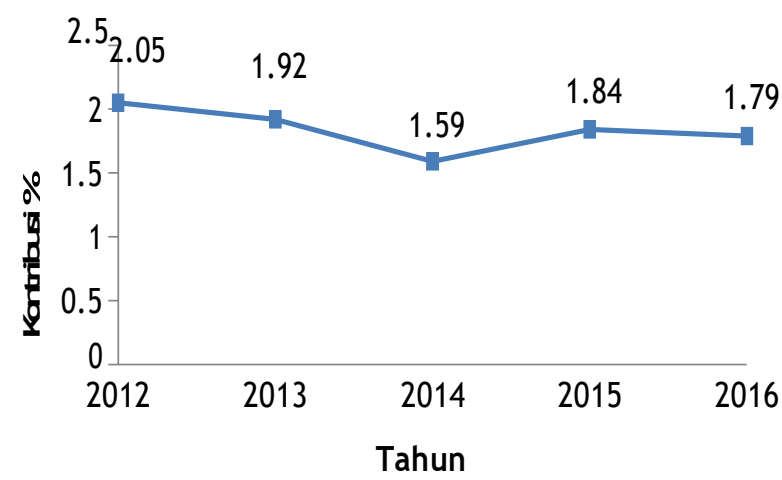

-T-Trend Kontribusi Pajak Reklame periode 2012-2016

\section{Gambar 4.1 Trend Kontribusi Pajak Reklame Periode 2012-2016}

Berdasarkan gambar 4.1 diatas dapat dilihat bahwa Trend kontribusi pajak Reklame terhadap Pendapatan Asli Daerah Kota Samarinda tahun 2012-2016 terjadi perubahan atau berfluktuasi, artinya kadang mengalami penurunan tetapi 
kemudian mengalami peningkatan antara 1,59\% sampai dengan 1,84\% yang masih tergolong kecil. Pada tahun 2012 persentase trend kontribusi pajak Reklame sebesar 2,05\% dan pada tahun 2013 mengalami penurunan sebesar $0,13 \%$. Pada tahun 2014 kembali mengalami penurunan sebesar $0,33 \%$ yakni $1,59 \%$ dan pada tahun 2015 meningkat $0,25 \%$ sebesar $1,84 \%$ dan kembali mengalami penurunan pada tahun 2016 sebesar 1,79\%. Jadi yang merupakan persentase Trend kontribusi Reklame tertinggi dari tahun 2012-2016, yaitu pada tahun 2012 sebesar 2,05\%

\subsubsection{Kontribusi Pajak Reklame terhadap Pendapatan Asli Daerah Kota Samarinda}

Hasil analisis kontribusi pajak Reklame terhadap Pendapatan Asli Daerah Kota Samarinda selama tahun 2012-2016 dapat dilihat dalam gambar berikut :

\section{Kontribusi Pajak Reklame \%}

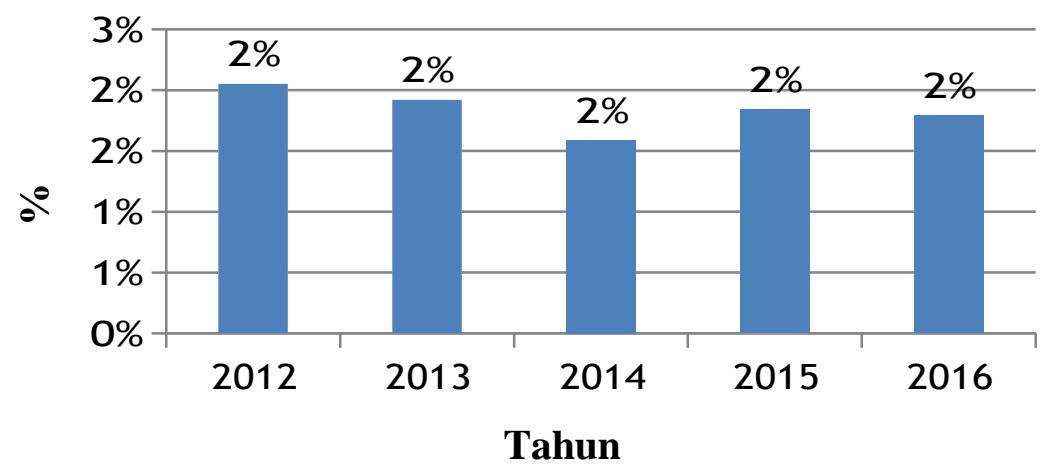

\section{Gambar 4.2 Kontribusi Pajak Reklame (\%)}

Berdasarkan gambar 4.2 diatas dapat dilihat bahwa kontribusi pajak Reklame terhadap Pendapatan Asli Daerah Kota Samarinda tahun 2012-2016 terjadi perubahan atau berfluktuasi, artinya kadang mengalami penurunan tetapi kemudian mengalami peningkatan antara $1,59 \%$ sampai dengan 1,84\% yang masih tergolong kecil. Pada tahun 2012 persentase kontribusi pajak Reklame sebesar 2,05\% dan pada tahun 2013 mengalami penurunan sebesar $0,13 \%$. Pada tahun 2014 kembali mengalami penurunan sebesar $0,33 \%$ yakni $1,59 \%$ dan pada tahun 2015 meningkat $0,25 \%$ sebesar $1,84 \%$ dan kembali mengalami penurunan pada tahun 2016 sebesar $1,79 \%$. Jadi yang merupakan persentase kontribusi Reklame tertinggi dari tahun 2012-2016, yaitu pada tahun 2012 sebesar 2,05\% yang dapat dilihat pada tabel 5.2.

Adanya penurunan kontribusi pada tahun 2013 dan faktor yang menyebabkan naik dan turunnya kontribusi pajak Reklame dalam meningkatkan Pendapatan Asli Daerah Kota Samarinda tahun 2012-2016, yaitu ada faktor-faktor yang menyebabkan kurangnya kontribusi yang 
diberikan pajak reklame terhadap pendapatan asli daerah Kota Samarinda adalah dikarenakan masih kurangnya kesadaran wajib pajak untuk membayar pajak reklame dengan inisiatif sendiri dan tepat waktu serta masih banyak wajib pajak khusus badan hukum yang berdomisili diluar wilayah Kota Samarinda sehingga memerlukan waktu dan biaya dari petugas untuk proses perizinan hingga pemungutan pajak.

Kurangnya Kontribusi Pajak Reklame yang kecil terhadap PAD juga disebabkan oleh kebijakan Pemerintah Kota Samarinda yang relative kecil dalam menetapkan target untuk penerimaan Pajak Reklame Di Kota Samarinda. Dimana seharusnya jika dilihat dilapangan seharusnya Samarinda sebagai Kota Perniagaan dan memiliki potensi yang sangat besar dalam bidadang reklame. Hanya saja meningkatnya pemesanan reklame di Kota Samarinda tidak diikuti dengan pengawasan dan control kepada wajib pajak sehingga masih banyak kebocoran yang terjadi dan menyebabkan banyak terdapat reklame-reklame liar dan para wajib pajak yang masih menunggak dan tidak teridentifikasi dengan tepat.

Untuk mendukung pengujian hipotesis diatas disajikan data Agar lebih jelasnya dalam memahami besarnya Kontribusi Pajak Reklame menurut ukuran kemampuan keuangan daerah menurut standar pusat dapat dilihat pada Tabel 5.4 dibawah berikut ini :

Tabel 4.4 Hasil Ukuran kemampuan Keuangan Daerah dilihat dari rasio Kontribusi Pajak Reklame terhadap Pendapatan Asli Daerah berdasarkan standar pusat.

\begin{tabular}{|l|l|l|c|}
\hline No & $\begin{array}{c}\text { Rasio Pajak Reklame } \\
\text { Terhadap PAD }\end{array}$ & \multicolumn{1}{|c|}{$\begin{array}{c}\text { Kemampuan } \\
\text { Keuangan } \\
\text { Pemerintah Kota } \\
\text { Samarinda }\end{array}$} \\
\hline 1 & $00,00 \%-10,00 \%$ & Sangat Kurang & \multirow{2}{*}{} \\
\hline 2 & $10,10 \%-20,00 \%$ & Kurang & \multirow{2}{*}{$1,83 \%$} \\
\hline 3 & $20,10 \%-30,00 \%$ & Sedang & \\
\hline 4 & $30,10 \%-40,00 \%$ & Cukup & \\
\hline 5 & $40,10 \%-50,00 \%$ & Baik & \\
\hline 6 & Diatas $50 \%$ & Sangat Baik & \\
\hline
\end{tabular}

Sumber : Penelitian dan Pengembangan Departemen Dalam Negeri Tahun 2012

Berdasarkan semua pembahasan hasil analisis data yang dilakukan dari tahun ketahun, dapat dilihat bahwa Kontribusi Pajak Reklame terhadap pendapatan Asli Daerah Kota Samarinda terbilang masih sangat kurang, karena nilai rata-ratanya dalam kurun 5 (lima) tahun terakhir yaitu pada tahun 2012 2016 adalah hanya sebesar 1,83\%. Hal ini menunjukkan bahwa Hipotesis Pertama yaitu "Trend Kontribusi Pajak Reklame dalam Pendapatan Asli Daerah Kota Samarinda periode 2012-2016 mengalami kenaikan setiap tahunnya" tidak sesuai dengan hasil analisis yang ada karena hasil perhitungan menunjukkan bahwa trend Kontribusi Pajak Reklame dalam Pendapatan Asli Daerah Kota Samarinda 
Periode 2012-2016 mengalami keadaan yang naik turun (fluktuatif) pada setiap tahunnya. Dengan demikian Hipotesis pertama ditolak (tidak dapat diterima).

Merujuk ukuran kemampuan yang ditentukan standar pusat ( penelitian dan pengembangan Dalam Negeri pada tahun 2012) maka jelas Kontribusi Pajak Reklame terhadap Pendapatan Asli Daerah Kota Samarinda masih sangat kurang berkontribusi.

Salah satu penyebab kurangnya Kontribusi Pajak Reklame adalah sistem perpajakan perpajakan reklame yang tidak diterapkan secara maksimal. Pasalnya pajak reklame yag diatur dalam Perda Nomor 04 tahun 2011 tentang pajak daerah, dan pajak reklame tidak berlaku untuk iklan dalam bentuk politik dan social.

Masalah lainnya selain pajak reklame dibidang politik dan social ialah bahwa ternyata reklame yang ada di Kota Samarinda sepeti baliho, billboard yang besar, ternyata banyak dikelola oleh orang-orang yang mengambil keuntungan dibidang iklan tersebut. Mereka membangun infrastruktur yang digunakan untuk mendirikan baliho, billboard. Setelah infrastruktur tersebut didirikan maka mereka akan menyewakan infrastruktur tersebut kepada perusahaan-perusahaan yang ingin mengiklankan barang dagangan perusahaan tersebut sehingga mereka yang membangun infrasruktur tersebut mendapat pendapatan yang lebih besar dibandingkan pajak yang mereka bayarkan kepada pemerintah yang pada akhirnya akan mengakibatkan pendapatan pemerintah yang tidak maksimal. Ternyata inilah masalah lain yang menyebabkan pendapatan pajak reklame Kota Samarinda mengalami fluktuasi dan kurang berkontribusi terhadap Pendapatan Asli Dearah Kota Samarinda.

\section{Kesimpulan}

Berdasarkan hasil analisis dan pembahasan data yang ada dalam penelitian ini, Kontribusi Pajak Reklame Terhadap Pendapatan Asli Dearah Kota Samarinda yang telah dikemukakan pada bab terdahulu, maka dapat diambil kesimpulan sebagai berikut :

1. Trend kontribusi pajak Reklame terhadap Pendapatan Asli Daerah Kota Samarinda tahun 2012-2016 terjadi perubahan atau berfluktuasi. Pada tahun 2012 persentase trend kontribusi pajak Reklame sebesar 2,05\% dan pada tahun 2013 mengalami penurunan sebesar 0,13\%. Pada tahun 2014 kembali mengalami penurunan sebesar $0,33 \%$ yakni $1,59 \%$ dan pada tahun 2015 meningkat $0,25 \%$ sebesar $1,84 \%$ dan kembali mengalami penurunan pada tahun 2016 sebesar 1,79\%. Jadi yang merupakan persentase Trend kontribusi Reklame tertinggi dari tahun 2012-2016, yaitu pada tahun 2012 sebesar 2,05\%.

2. Dapat dilihat bahwa Kontribusi Pajak Reklame terhadap pendapatan Asli Daerah Kota Samarinda terbilang masih sangat kurang, karena nilai rataratanya dalam kurun 5 (lima) tahun terakhir yaitu pada tahun $2012-2016$ adalah hanya sebesar $1,83 \%$.

\section{DAFTAR PUSTAKA}


Halim, Abdul 2008. Akuntansi sector public Akuntansi Keuangan Daerah, Edisi 3. Salemba 4. Jakarta

Ilmudasar.com/2017/09/pengertian-fungsi-sumber-unsur-pajakdaerah

jurnal.id/blog/2018/pembahasan tentang perhitungan pajak reklame

Nurcholis, Hanif. 2007, Teori dan Praktik Pemerintahan dan Otonomi Daerah, PT Grasindo, Jakarta.

Peratutan Daerah. 2006. Kota Samarinda Nomor 7 Tentang Pajak Reklame

Sasaja, Zulkifli. "Pajak reklame dan dasar pengenaan pajak reklame”. 18

April 2018. https://.wordpress.com/2014/04/03/pajak-reklame/

Sutrisno. 2007. Manajemen Keuangan : Teori, Konsep dan Aplikasi, Ekonisia T, Yogyakarta.

Soemarso. 2007. Perpajakan Pendekatan Komperhensif, Salemba Empat,Jakarta.

Suandy, Erly. 2002. Hukum Pajak, Edisi 3. Salemba 4. Jakarta

Sugianto. 2008. Pajak dan Retribusi Daerah (Pengelolaan Pemerintah Dearah Dalam aspek Keuangan, Pajak, dan Retribusi Daerah, PT Gramedia Widiasarana Indonesia. Jakarta

Siahaan, P. Marihot. 2008. Pajak Daerah dan Retribusi Daerah, PT Rajagrafindo. Persada. Jakarta

Undang-Undang Nomor 32 Tahun 2004 tentang Pemerintahan Daerah

Undang-Undang Nomor 33 Tahun 2004 tentang Perimbangan Keuangan antara Pemerintah Pusat dan Daerah

Undang-undang No. 34 tahun 2000 tentang Pajak dan Retribusi daerah pasal 2 ayat 1 dan ayat 2 tentang jenis pendapatan pajak daerah untuk provinsi

Undang-undang No. 34 Tahun 2000 tentang perubahan atas undangundang Republik Indonesia No. 18 Tahun 1997 tentang Pajak Daerah dan Retribusi Daerah pasal 2 ayat 1 dan 2

Wonata, Azarya.2008. Perbandingan Kontribusi Pajak Bumi dan Bangunan (PBB) dan Bea Perolehan hak atas Tanah dan Bangunan sebelum dan sesudah otonomi daerah terhadap pendapatan daerah kota Balikpapan, Skripsi IESP. Samarinda. 
Yani, Ahmad. 2008. Hubungan Keuangan antara Pemerintah Pusat dan Daerah di Indonesia, PT Rajagrafindo Persada, Jakarta. 